\title{
Species Composition, Diversity and Habitat Assessment of Mangroves in the Selected Area along Butuan Bay, Agusan Del Norte, Philippines
}

\author{
Alvin B. Goloran1, Calagui Laurence'2, Betco Glenn³, Mulgado April Tricia1 \\ ${ }^{1}$ Department of Education, Division of Butuan City, Pigdaulan National High School, Butuan City, Philippines \\ ${ }^{2}$ Department of Biology, College of Arts and Sciences, Caraga State University, Ampayon, Butuan City, Philippines \\ ${ }^{3}$ City Environment and Natural Resources, City Government of Butuan, Brgy. Doongan, Butuan City, Philippines \\ Email: goloranalvin@gmail.com
}

How to cite this paper: Goloran, A.B., Laurence, C., Glenn, B. and Tricia, M.A. (2020) Species Composition, Diversity and Habitat Assessment of Mangroves in the Selected Area along Butuan Bay, Agusan Del Norte, Philippines. Open Access Library Journal, 7: e6249.

https://doi.org/10.4236/oalib.1106249

Received: March 20, 2020

Accepted: April 5, 2020

Published: April 8, 2020

Copyright $\odot 2020$ by author(s) and Open Access Library Inc.

This work is licensed under the Creative Commons Attribution International License (CC BY 4.0).

http://creativecommons.org/licenses/by/4.0/

\begin{abstract}
Philippines has about 7100 islands with 3 major islands, Luzon, Visayas, and Mindanao and has about $18,000 \mathrm{~km}$ of shorelines with vast areas of mangrove ecosystem. Government policies, which dictated development in both the uplands and coastal areas, have been based mainly on abundant available resources without due consideration for sustainability. The study was conducted for the purpose to identify mangroves diversity and assessment in selected area along Butuan Bay, Agusan del Norte, particularly in the coastal line of Butuan City, Magallanes and Buenavista. Random sampling was used and had a total number of 9 stations having three (3) $10 \times 10$ meters' quadrat each area. Results revealed a total of 12 species of mangroves within the areas along Butuan Bay. Family Avicenniaceae and Rhizoporaceae dominated the area. Avicennia alba and Rhizopora mucronata dominated in all sampling stations. Eleven (11) species were recorded to be Least Concern and only one species was considered Vulnerable (Avicennia rumphiana). Among the species, Acanthus ebracteatus was the most dominant species followed by palm mangrove Nypa fruticans. Based on the results, mangrove areas in the selected area along Butuan Bay fall under the category of very low biodiversity with a value of 1.79 . This means that all selected areas experienced very high disturbances from anthropogenic activity.
\end{abstract}

\section{Subject Areas}

Environmental Sciences, Natural Geography 


\section{Keywords}

Diversity, Mangrove Assessment, Anthropogenic Factors, Butuan Bay

\section{Introduction}

Mangroves are usually located along coastal and marine areas which play a vital role to sustain the balance of the shoreline ecosystem. Mangrove vegetation includes trees, shrubs, palms and ground ferns that grow within the intertidal areas of coastal and estuarine margins [1]. Mangrove forests cover approximately 20 million hectares worldwide and are the main vegetation type in protected intertidal areas along tropical [2] and subtropical coastlines being limited in distribution by the temperature of the sea water and the winter position of the $20^{\circ} \mathrm{C}$ isotherm [3]. Further, mangrove population and species grow in highly humid to extremely parched conditions with several substrate types including clay, loam, peat, sand, coral rubble, rock and some near sea grass beds [4]. Mangroves provide habitat for many juvenile fishes and other faunal species. Mangroves provide many and useful human products, resources and ecological services such as wood-fire, ethno-medicinal, clean air and typhoon/floods protection. Moreover, it helps maintain ecological balance in an ecosystem. Accordingly, mangroves maintain coastal water quality and form a barrier for coastal protection from wave storm and flood damage [5]. Mangroves are also used by many indigenous peoples for traditional uses including as a source of medicine [6] as well as for building materials [7]. Mangroves forest is an important ecosystem that provides surrounding habitats with many ecological services and can be exploited to the benefit of many communities. They are however under threat from a variety of human activities and large areas of this forest are being lost. Anthropogenic activities in all areas within the coastal areas and other local development provide threat to this mangrove community.

Philippines has about 7100 islands with 3 major islands, Luzon, Visayas and Mindanao, and has about $18,000 \mathrm{~km}$ of shorelines and vast areas of mangroves totaling to 500,000 hectares. The development of coastal resources in the Philippines has been traditionally exploitative in nature. Government policies, which dictated development in both the uplands and coastal areas, have been based mainly on abundant available resources without due consideration for sustainability [8]. Department of Environment and Natural Resources of the Philippines recorded last 2005 over-exploitation, conversion of areas to various uses, and the simultaneous logging of watersheds in the uplands. The country's remaining mangrove area was only 117,700 hectares [9]. And up to this year, the land conversion including mangrove areas in the Philippines due to the increase of population risks the species composition of mangroves in every coastal area. Large areas of mangrove forests may often be cleared to make way for shrimp aquaculture in developing countries [10]. The rehabilitation, conservation and pro- 
tection of mangrove forest along coastal areas of the Philippines should be the collaborative effort between the LGU's, DENR and All Stakeholders to make sustainable long term plan identified and recognized that Philippines has more or less 36 species of mangroves [11].

To address some issues on mangrove degradation and habitat loss in Butuan City specially along Butuan Bay, this study purposely conducted to identify mangrove diversity, habitat assessment and species composition as basis for proper and systematic approach of mangroves protection and rehabilitation to be included in City/Municipality Forest Land Use Plan (FLUP). This will also be served as the basis for the creation of ordinance and other related policies that promote mangrove protection along Butuan Bay.

\section{Materials and Methods}

\subsection{Study Date}

The study was conducted from the month of November and December, 2019 along the selected areas of Butuan Bay particularly in the Municipality of Magallanes, Buenavista and City of Butuan.

\subsection{Study Area}

The selected areas were along the Butuan Bay particularly in the Municipality of Magallanes $\left(9^{\circ} 2^{\prime} 14.07^{\prime \prime} \mathrm{N}, 125^{\circ} 31^{\prime} 15.79^{\prime \prime} \mathrm{E}\right)$ Buenavista $\left(8^{\circ} 58^{\prime} 45.65^{\prime \prime} \mathrm{N}, 125^{\circ} 24^{\prime} 5.71^{\prime \prime E}\right)$ and City of Butuan $\left(8^{\circ} 59^{\prime} 32.76^{\prime \prime} \mathrm{N}, 125^{\circ} 28^{\prime} 39.71^{\prime \prime E}\right)$. These were selected by the researcher based on the conducted reconnaissance last October, 2019 in all municipality surrounding the Butuan Bay. Figure 1 shows the general map of $\mathrm{Bu}$ tuan Bay as well as the sampling stations established for this study.

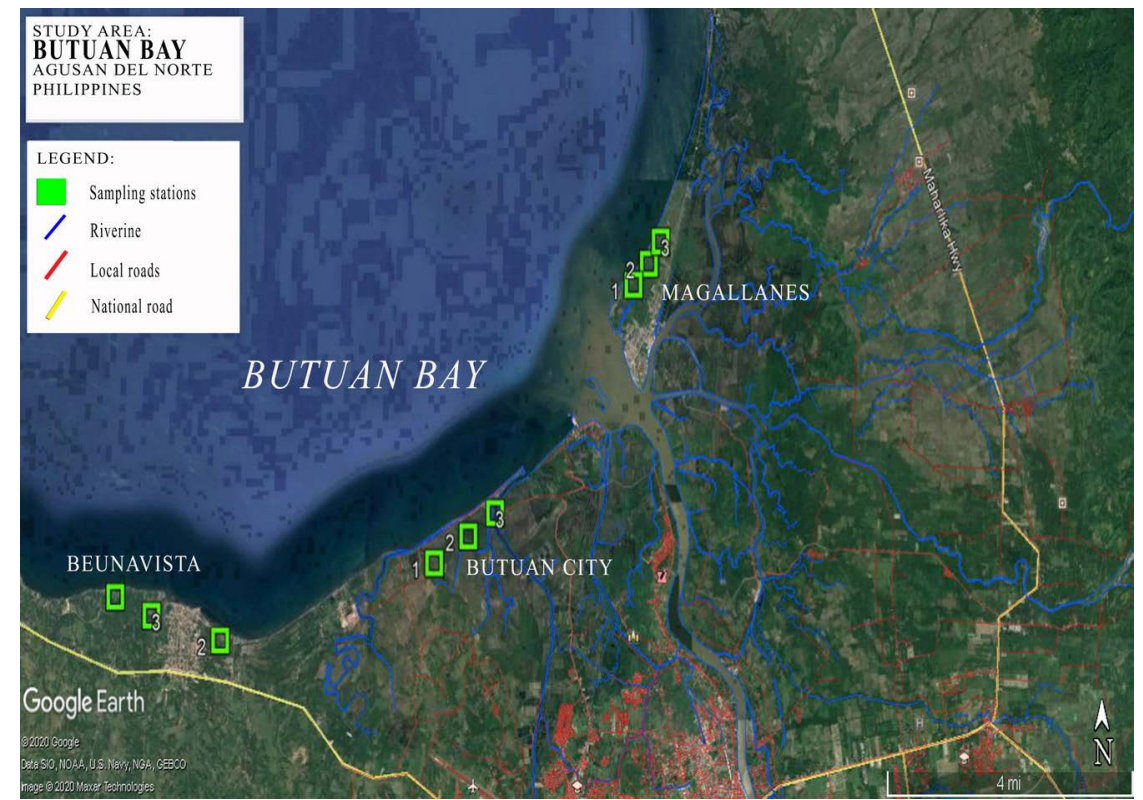

Figure 1. Study area and sampling stations of mangrove assessment along Butuan Bay, Agusan Del Norte, Butuan City. 


\subsection{Transect Line and Sampling Stations}

Figure 1 above shows the establishment of 9 permanent sampling stations in 3 areas (Butuan, Magallanes, \& Beunavista) within the mangrove areas along $\mathrm{Bu}$ tuan Bay. Every area has (3) three $10 \times 10$ were established randomly with a distance ranges 15 - 30 meters or depends in the structure of mangrove community [12]. Random sampling allows the researcher to easily determine the composition of mangroves and its type of species [12]. It is also the easiest way used by many studies because it is difficult to measure or count all the individuals within a population, including time and money constraints, a large number of individuals, or difficulty in accessing some areas. If it is not possible to measure or count all the individuals within a population, researcher must select an area of the population to sample. Because individuals are rarely evenly distributed within an area, it is important to sample randomly to ensure that we get a true representation of the population [13]. Mangrove species inside the plot were identified, counted and measured including diameter breast height ( dbh) measured 2 meters from the ground, canopy cover (cc) in meter using only estimation, and average height $(\mathrm{h})$ in meter was measured with improvised calibrated stick. Three (3) $1 \times 1 \mathrm{~m}$ sub plot were established in counting of individuals for seedlings and saplings (planted seedlings not included in the counting). Each mangrove within the plots was characterized as seedling, sapling and mature tree [14]. The DBH (in $\mathrm{cm}$ ) was calculated using the formula: circumference/3.1416 [15].

\subsection{Mangrove Composition and Identification}

The mangroves within plots were identified and classified taxonomically and were identified using the field guide and taxonomic key manual to Philippines Mangroves by Primavera et al. [11].

\subsection{Diversity Indices}

Using Paleontological Statistical Software Package (PAST), Shannon-Weiner diversity index, species dominance, taxa and evenness were only calculated [16]. PAST software is the free-ware widely used by many researchers for flora and fauna inventory including mangroves. Shannon-Weiner was classified based on a modified scale [17] (Table 1).

Table 1. Modified Fernando (1998) Diversity scale.

\begin{tabular}{cc}
\hline Relative Values & Shannon-Wiener Index $\left(\mathrm{H}^{\prime}\right)$ \\
\hline Very High & $3.50-4.00$ \\
High & $3.00-3.49$ \\
Moderate & $2.50-2.99$ \\
Low & $2.00-2.49$ \\
Very Low & 1.99 and below \\
\hline
\end{tabular}




\subsection{Habitat Assessment}

For the habitat assessment of mangroves, percent estimated canopy cover, regeneration per $\mathrm{m}^{2}$ and average height were calculated. Height was measured using the modified stick wood in meter $(\mathrm{m})$.

$$
\begin{gathered}
\% \text { canopy cover }=\frac{\text { Total canopy cover of all plots }}{\text { Total numbers of plots }} \\
\text { Regeneration per } \mathrm{m}^{2}=\frac{\text { Total regeneration count }}{\text { Total of regeneration plots }} \\
\text { Average height }=\frac{\text { Total heights of trees recorded }}{\text { Total number of trees recorded }}
\end{gathered}
$$

\subsection{Ecological Status and Population Trends}

Mangrove species status, occurrences and trends are classified and identified using the recorded online tool, the International Union for Conservation of $\mathrm{Na}$ ture (IUCN) red list and the DENR Administrative Order No. 11 series 2017 known as the Updated List of Threatened Philippine Plants and their Categories [18] [19].

\section{Results and Discussions}

A total of 12 species of mangroves were recorded and identified in the selected area along Butuan Bay. Among the area, Butuan City obtained the highest number of mangroves species compared to Magallanes and Buenavista respectively. Figure 2 below shows the number of mangroves species recorded in the selected areas.

Sonneratia alba, $H$. littoralis and $X$. granatum were species of mangroves rarely encountered. And the $R$. mucronata, B. tersa, N. fruticans and E. agallocha were the most common species in all areas. Table 2 below is the species listing in 3 identified areas.

Magallanes, Agusan del Norte recorded very low in terms of number of species that's why this area is one of the active site for many environmental activities such

\section{Mangrove Species}

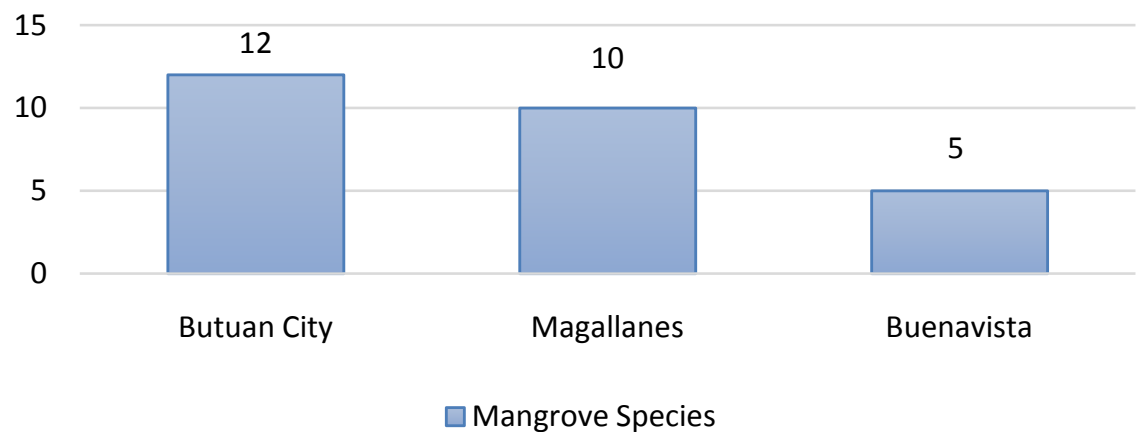

Figure 2. Percentage of mangrove species recorded in 3 sampled areas along Butuan Bay, Agusan del Norte. 
Table 2. Species listing of mangroves along Butuan Bay.

\begin{tabular}{cccc}
\hline Species & Butuan City & Buenavista & Magallanes \\
\hline A. ebracteatus & $X$ & $X$ & \\
A. corniculatum & $X$ & $X$ & \\
A. alba & $X$ & $X$ & \\
A. rumphiana & $X$ & $X$ & $X$ \\
B. tersa & $X$ & $X$ & \\
E. agallocha & $X$ & $X$ & \\
H. littoralis & $X$ & $X$ & $X$ \\
N. fruticans & $X$ & $X$ & \\
R. mucronata & $X$ & $X$ & \\
S. alba & $X$ & & \\
S. caseolaris & $X$ & $X$ & \\
X. granatum & $X$ & & \\
\hline
\end{tabular}

as mangrove planting or Arbor Day for the Department of Environment and Natural Resources (DENR). The study identified that globally, mangrove areas are declining rapidly as they cleared for coastal development and aquaculture and logged for timber and fuel production [20]. These ideas supported the actual scenario in the 3 selected sampling areas wherein these experience massive land conversion for many economical purposes.

The municipality of Magallanes obtained the lowest number of mangrove species due to many anthropogenic disturbances. As defined in the study [21], anthropogenic activities had changed the soil type from swampy to sandy mud soil which contributes to the sudden changes of environment to the true mangroves. In terms of abundance, Buenavista, Agusan del Norte obtained the highest value compared to other area and these are dominated by $A$. alba and $A$. ebracteatus. Figure 3 below shows the abundance and richness of mangrove species in 3 areas.

Among the mangrove species only A. rumphiana was noted to be Vulnerable $(\mathrm{V})$ in terms of ecological status as defined by the International Union of Conservation of Nature (IUCN) and the rest are Least Concern (LC) [19]. But all mangroves species identified were decreasing in terms of population and stability. As defined by more than $35 \%$ of the world's mangroves already gone and $50 \%$ in countries such as India, the Philippines and Vietnam [19]. The rapid changes in the mangroves environment clearly affect the species in many ways and considered as the one of the worlds threatened tropical ecosystems.

In terms of diversity, Butuan City obtained the highest value of 2.178 , but these still falls under the low diversity index scaled [17]. The diversity index of all selected areas along Butuan Bay is also low (Figure 4 and Figure 5). This means that the mangrove ecosystem is in problem and in need of further rehabilitation, protection and conservation. 


\section{Abundance}

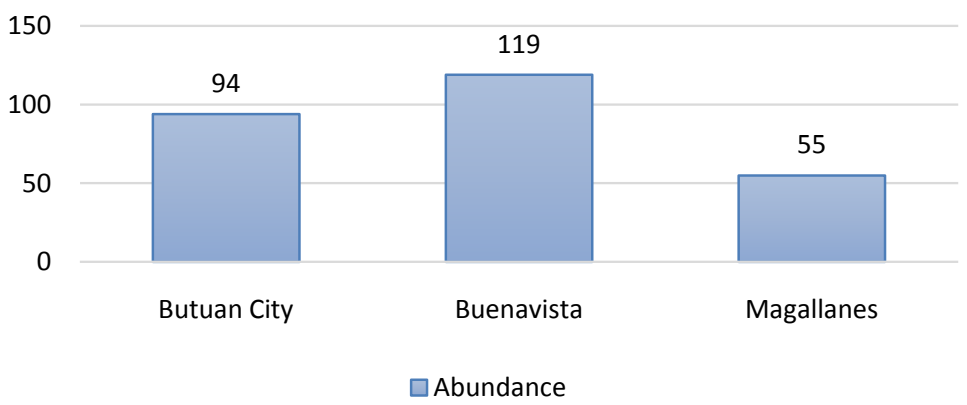

Figure 3. Abundance of mangroves in 3 selected area along Butuan Bay, Agusan del Norte, Philippines.

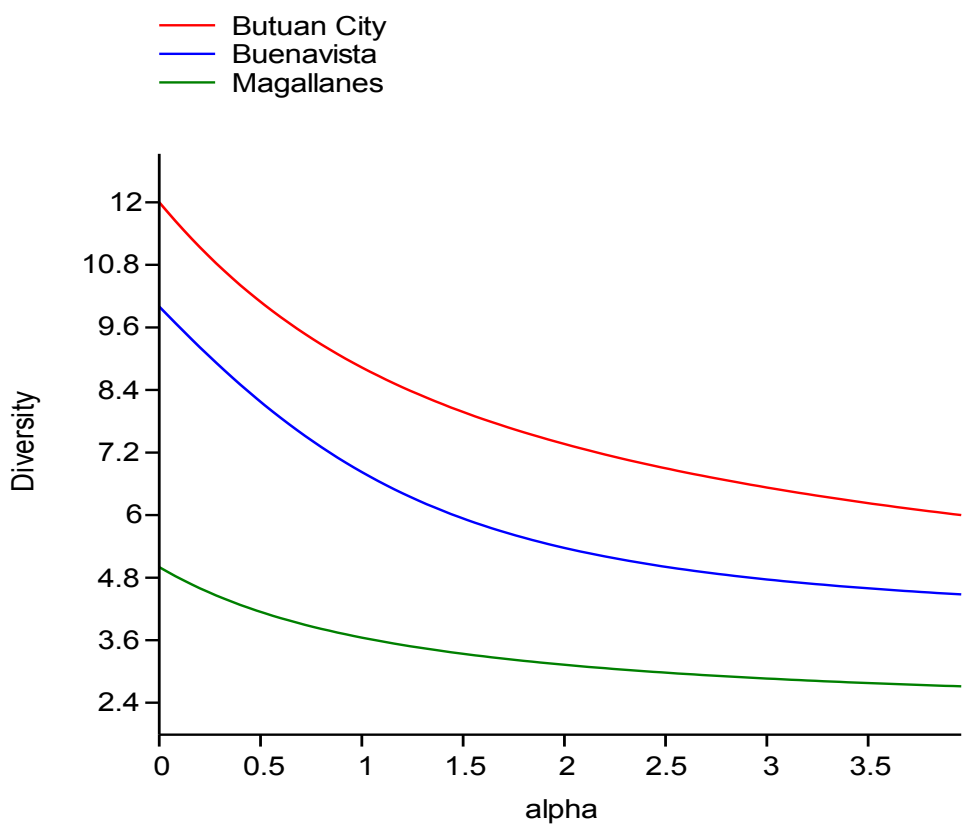

Figure 4. Diversity Index of 3 sampled areas for mangrove assessment.

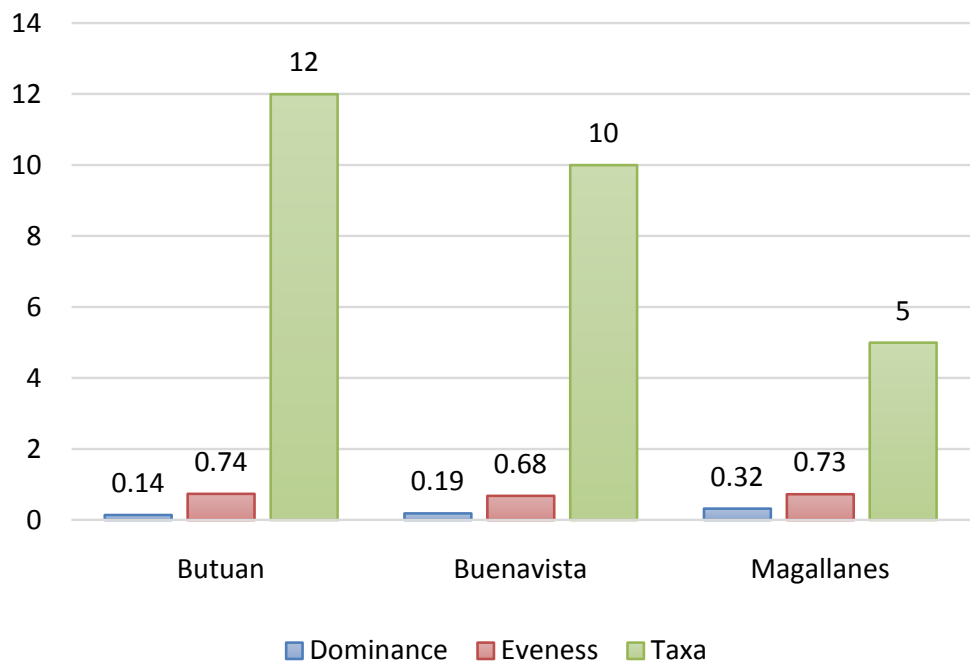

Figure 5. Species dominance and evenness of 3 selected areas. 
The dominance value of Magallanes was due to the presence and the abundance of $R$. mucronata and $N$. fruticans. These high value of dominance compared to other indicates the importance of these mangroves species in the area. All sampled areas were almost the same value of eveness. These mean that the selected sampling area has the similarity of frequencies of the different units making up a population. Eveness and richness were both complementary in studying species diversity [22]. All value acquired were calculated using Paleontological Statistical Software or PAST [23].

Mangrove canopy cover was recorded, and Butuan City obtained the highest value which has an estimated cover of $63.33 \%$ followed by Buenavista, 59.33\% and Magallanes, $53.33 \%$. The high number of species, canopy cover per trees and diameter breast high $(\mathrm{DBH})$ contributed to the value of canopy cover as it was observed that Butuan still have many old growth mangrove forest. The influence of canopy covers upon the regeneration of plants [23]. And in mangroves maintaining its cover play important role not just to the regeneration of same species but it also provides shelter to many faunal species. The 3 sampled areas were considered to be vulnerable as it indicated in its canopy cover going down to almost 50\% due mainly to many anthropogenic factors. Table 3 below is the estimated canopy cover, average tree height, average crown covers and regeneration per square meter to determine the habitat assessment.

Anthropogenic factors influence mainly the number of species of mangroves in all selected areas. Researcher was able to observe several of these and among are improper solid wastes disposal, waste water problem, kaingin, human consumptions, illegal housing, land conversion, coastal conversion and development. These findings support the findings [24] that mangrove habitats are regressing at an alarming rate due to direct anthropogenic impacts and global change.

\section{Conclusions}

The mangrove diversity and habitat assessment are important tools to determine the present status of this ecosystem along Butuan Bay. Finding shows that the 3 sampled areas namely Butuan City, Buenavista and Magallanes obtained low diversity index and had only 12 species (33\% of Philippine mangroves). This means that the mangrove community present in these area was under ecological threat due to many identified anthropogenic factors. Among the locations, the Municipality of Magallanes had the lowest number of species which provides immediate attention for rehabilitation and protection. The overall result of these

Table 3. Habitat assessment of mangroves per area.

\begin{tabular}{ccccc}
\hline Area & DBH $(\mathrm{cm})$ & H $(\mathrm{m})$ & C.C $(\mathrm{m})$ & Reg. $\mathrm{m}^{2}$ \\
\hline Butuan & 69.3 & 15.1 & 8.4 & 7.0 \\
Buenavista & 65.2 & 12.3 & 5.9 & 6.0 \\
Magallanes & 53.5 & 11.8 & 4.1 & 4.0 \\
\hline
\end{tabular}


studies provides attention to the concern government agencies, stakeholders and non-government agencies to allot budget in the future, to be included the environmental planning in 3 local government units for possible rehabilitation, protection and conservation.

\section{Recommendations}

The Department of Environment and Natural Resources (DENR) as the leading government agency, continues to allot budget in coordination with LGU's to rehabilitate the degraded remaining mangrove forest. Local Government Unit must provide preventive measures in protecting its remaining mangrove claimed. Government must consider these results to be used to their Comprehensive Land Use Plan and Forest Land Use Plan (FLUP). There must have a frequent monitoring and educational information campaign to the areas that have mangrove forest. Academe and other researcher must continue to conduct scientific studies in relation to mangrove management for present and future purposes.

\section{Acknowledgements}

The study was supported by the Caraga State University, City Environment and Natural Resources (City ENRO), City Government of Butuan City and Pigdaulan National High School. This manuscript was guided by Mr. Meljan T. Demetillo, Ph.D.

\section{Conflicts of Interest}

The authors declare no conflicts of interest regarding the publication of this paper.

\section{References}

[1] Benfield, S. (2002) An Assessment of Mangrove Cover and Forest Structure in Punta Mala Bay, Panama City, Panama by Means of Field Survey and GIS Analysis of Aerial Photographs. Master's Degree, Department of Civil and Offshore Engineering/School of Life Sciences, Heriot-Watt University, Edinburgh, Scotland.

[2] Godoy, M.D. and de Lacerda, L.D. (2015) Mangroves Response to Climate Change: A Review of Recent Findings on Mangrove Extension and Distribution. Anais da Academia Brasileira de Ciencias, 87, 651-667. https://doi.org/10.1590/0001-3765201520150055

[3] Hogarth, P. (2007) The Biology of Mangroves and Seagrass. Department of Biology, University of New York, Oxford University Press, New York.

[4] Nagelkerken, I. (2009) Evaluation of Nursery Functions of Mangroves and Sea Grass Beds for Tropical Decapods and Reef Fishes: Pattern and Underlying Mechanisms. Institute for Water and Wetland Research, Faculty of Science, Radboud University Nijmegen, the Netherlands. https://doi.org/10.1007/978-90-481-2406-0_10

[5] GradesFixer (2018) Mangroves: Importance and Threats. https:/gradesfixer.com/free-essay-examples/mangroves-importance-and-threats/ 
[6] Bandaranayake, W.M. (1998) Traditional and Medicinal Uses of Mangroves. Mangroves and Salt Marshes, 2, 133-148. https://doi.org/10.1023/A:1009988607044

[7] Walters, B.B. (2005) Patterns of Local Wood Use and Cutting of Philippine Mangrove Forests. Economic Botany, 59, 66-76. https://doi.org/10.1663/0013-0001(2005)059[0066:POLWUA]2.0.CO;2

[8] Melana, E.E., et al. (2005) Mangroves Management and Development in the Philippines. SEAFDEC/AQD Institutional Repository (SAIR).

[9] DENR (2005) Forestry Statistics 2005. Forest Management Bureau, Department of Environment and Natural Resources, Quezon City.

[10] Primavera, J.H. (2000) Development and Conservation of Philippine Mangroves: Institutional Issues. Ecological Economics, 35, 91-106. https://doi.org/10.1016/S0921-8009(00)00170-1

[11] Primavera, J.H., Sadaba, R.B., Lebata, M.J.H.L. and Altamirano, J.P. (2004) Handbook of Mangroves in the Philippines-Panay. SEAFDEC Aquaculture Department, Iloilo.

[12] Canizares, L.P. and Seronay, R.A. (2016) Diversity and Species Composition of Mangroves in Barangay Imelda, Dinagat Island, Philippines. AACL Bioflux, 9, 518-526. http://www.bioflux.com.ro/aacl

[13] Hughes, N.K., Burley, A.L., King, S.A. and Downey, P.O. (2009) Monitoring Manual for Bitou Bush Control and Native Plant Recovery. Department of Environment, Climate Change and Water, Sydney.

[14] Deguit, E.T., Smith, R.P., Jatulan, W.P. and White, A.T. (2004) Participatory Coastal Resource Assessment Training Guide. Coastal Resource Management Project of the Department of Environment and Natural Resources, Cebu City, Philippines.

[15] English, S., Wilkinson, C. and Baker, V. (1997) Survey Manual for Tropical Marine Resources. Chapter 3-Mangrove Survey. Australian Institute of Marine Science, Townsville, 119-196.

[16] Hammer, O., Harper, D.A. and Ryan, P.D. (2001) Past: Paleontological Statistics Software Package for Education and Data Analysis. Palaeontologia Electronica. http://palaeo-electronica.org

[17] Fernando, E.S. (1998) Forest Formations and Flora of the Philippines: Handout in FBS 21. College of Forestry and Natural Resources, University of the Philippines at Los Baños (Unpublished).

[18] DENR (2017) Administrative Order No. 11, List of Threatened Plants of the Philippines. Department of Environment and Natural Resources, Philippines.

[19] IUCN (2020) The IUCN Red List of Threatened Species. Version 2020-1. https://www.iucnredlist.org

[20] Polidoro, B.A., et al. (2010) The Loss of Species: Mangrove Extinction Risk and Geographic Areas of Global Concern. PLoS ONE, 5, e10095.

https://doi.org/10.1371/journal.pone.0010095

[21] Numbere, A.O. (2018) Mangrove Species Distribution and Composition, Adaptive Strategies and Ecosystem Services in the Niger River, Delta, Nigeria. https://doi.org/10.5772/intechopen.79028

[22] Lemieux, J. and Cusson, M. (2014) Effects of Habitat-Forming Species Richness, Evenness, Identity, and Abundance on Benthic Intertidal Community Establishment and Productivity. PLOS ONE, 9, e109261. https://doi.org/10.1371/journal.pone.0109261

[23] Vickers, A.D. and Palmer, S.C.F. (2000) The Influence of Canopy and Other Factors 
upon the Regeneration of Scots Pine and Its Associated Ground Flora within Glen Tanar National Nature Reserve. Forestry, 73, 37-49.

https://doi.org/10.1093/forestry/73.1.37

[24] Carugati, L., et al. (2018) Impact of Mangrove Forests Degradation on Biodiversity and Ecosystem Functioning. Scientific Reports, 8, Article No. 13298.

https://doi.org/10.1038/s41598-018-31683-0 